\title{
Penyusunan Strategi Pemasaran Islam dalam Berwirausaha di Sektor Ekonomi Kreatif Pada Masa Pandemi Covid-19
}

\author{
Moh Khoiri Abdi \\ UIN Sunan Gunung Djati Bandung \\ Email:abdiresec@gmail.com \\ Novi Febriyanti \\ UIN Sunan Ampel Surabaya \\ Email:novikfbr@gmail.com
}

\begin{abstract}
In the middle of the development of UMKMs that were not too good in early 2020, UMKMs in Indonesia were again tested with the Covid-19 outbreak in the middle of the Indonesian people. The spread of the Covid-19 virus has a direct impact on the drastic decline in the economy of UMKMs, because every citizen, even school students, has a day off to stay at home, as a result, UMKM companies are hampered in sales and production. This article intends to analyze how the preparation of a Islamic marketing strategy that can be done during the Covid-19 pandemic and supporting factors in entrepreneurship in the creative economy sector during the Covid-19 pandemic. Using qualitative research methods with a library research approach. The results of this study prove that the preparation of a Islamic marketing strategy in entrepreneurship in the creative economy sector can be planned through STP (Segmenting, Targetting and Positioning) to attract consumers. While the supporting factors in entrepreneurship in the creative economy sector during the Covid-19 pandemic to run effectively and efficiently include the concept of promotion, service excellet customer rewards, affiliations or partnerships and social capital.
\end{abstract}

Keywords: Islamic Marketing Strategy, Business, Creative Economy.

\begin{abstract}
Abstrak: Di tengah perkembangan Usaha Mikro Kecil Menengah (UMKM) yang belum terlalu baik di awal tahun 2020, UMKM di Indonesia kembali diuji dengan wabah Covid-19 di tengah masyarakat Indonesia. Penyebaran wabah Covid-19 memberikan dampak yang berimbas langsung terhadap penurunan secara drastis ekonomi UMKM, karena setiap warga bahkan murid sekolah pun diliburkan agar tetap berada di dalam rumah, akibatnya perusahaan UMKM terhambat dalam penjualan dan juga produksi. Artikel ini bermaksud ingin menganalisis bagaimana penyusunan strategi pemasaran Islam yang dapat dilakukan pada masa pandemi Covid19 dan faktor pendukung dalam berwirausaha di sektor ekonomi kreatif pada masa pandemi Covid-19. Menggunakan metode penelitian kualitatif dengan pendekatan library research. Hasil penelitian ini membuktikan bahwa penyusunan strategi pemasaran dalam berwirausaha pada sektor ekonomi kreatif dapat direncanakan melalui STP (Segmenting, Targetting dan Positioning) untuk menarik konsumen. Sedangkan faktor pendukung dalam berwirausaha di sektor ekonomi kreatif pada masa pandemi Covid-19 agar berjalan secara efektif dan efisien diantaranya adalah konsep promotion, service excellet customers rewards, afiliasi atau kemitraan dan modal sosial.
\end{abstract}

Kata Kunci: Strategi Pemasaran Islam, Bisnis, Ekonomi Kreatif 


\section{PENDAHULUAN}

Pada masa pandemi Covid-19, segala aktivitas dibatasi. Menurut Bank Dunia, dampak ekonomi dari Covid-19 ini akan menghentikan usaha hampir 24 juta orang di Asia Timur dan Pasifik. Di bawah skenario terburuknya, Bank Dunia juga memperkirakan hampir 35 juta orang akan tetap dalam kemiskinan. Bahkan, melalui sejumlah skenario dengan mempertimbangkan berbagai garis kemiskinan, Bank Dunia memperkirakan jumlah orang yang hidup dalam kemiskinan ekstrim akan meningkat hingga 922 juta di seluruh dunia. ${ }^{1}$ Sedangkan menurut Menteri Keuangan Republik Indonesia, Sri Mulyani Indrawati memprediksikan pertumbuhan ekonomi dalam keadaan terburuknya mencapai minus $0,4 \% .^{2}$ Di antara upaya yang disuarakan dan dilakukan oleh berbagai negara di dunia dalam meminimalisir penyebaran virus Corana atau Covid-19 adalah dengan menajaga jarak sosial atau physical distancing. Namun gerakan tersebut berdampak pada penurunan aktivitas ekonomi secara global. Rasa cemas dan panik tentu mendarat di hati para pelaku bisnis ketika krisis ekonomi menyebar di hampir seluruh negara di dunia akibat Covid-19 ini. Adanya pembatasan keluar rumah dengan tetap menjalankan kegiatan di rumah saja dan karantina masing-masing membuat pelanggan semakin terasingkan. Konsumen hanya akan melakukan pembelian barang primer dan cenderung menghindari pembelian barang sekunder apalagi tersier sehingga berdampak pada sisi permintaan (supply). ${ }^{3}$

Berdasarkan hukum supply dan demand, penurunan permintaan akibat program tetap di rumah saja (stay at home) pada gilirannya akan memicu penurunan jumlah produksi. Selanjutnya, proses penurunan perekonomian menunjukkan bahwa bencana yang ditimbulkan oleh Covid-19 ini telah merusak kelancaran mekanisme pembentukan pasar di antara minimnya permintaan dan penawaran. Adanya kontraksi dalam produksi, yang mengarah kepada kontraksi dalam permintaan, pada akhirnya melenyapkan surplus ekonomi. Mengingat bahwa aspek-aspek vital ekonomi yaitu supply, demand dan supply-chain telah terganggu, maka dampak krisis akan dirasakan secara merata ke seluruh lapisan atau tingkatan masyarakat. ${ }^{4}$ Berhubung karena ketahanan setiap lapisan atau tingkatan tersebut berbeda-beda, maka masyarakat ekonomi golongan menengah ke bawah khususnya mikro dan informal dengan pendapatan harian, tentu menjadi kelompok yang paling rentan terkena dampaknya. Salah satunya berdampak terhadap terbatasnya operasional pebisnis dalam berwirausaha dan

The World Bank, "World Bank Group and Covid-19 (Coronavirus)", http://www.worldbank.org/en/who-we-are/news/coronavirus-covid19, diakses pada tanggal 20 Mei 2020.

${ }^{2}$ Kementerian Keuangan. "Solusi Ekonomi dan Keuangan Islam Saat Pandemi COVID-19", https://www/kemenkeu.go.id/publikasi/artikel-dan-opini/solusi-ekonomi-dan-keuangan-islam-saatpandemi-Covid-19/, diakses pada tanggal 20 Mei 2020.

${ }^{3}$ Azwar Iskandar, Bayu Taufiq Possumah, Khaerul Akbar, "Peran Ekonomi dan Keuangan Sosial Islam Saat Pandemi Covid-19”, SALAM: Jurnal Sosial dan budaya Syar-i, Vol. 7, No. 7, (2020), 625-638.

${ }^{4}$ Intitut Tazkia, Tujuh Paket Ekonomi dan Keuangan Syariah Mengatasi Dampak Krisis Covid-19, (Bogor: Intitut Tazkia, 2020), 1-7.

el-Qisț: Journal of Islamic Economics and Business (JIEB) 
berkurangnya konsumen yang berbelanja secara langsung dibandingkan hari biasanya. 5

Dalam hal ini, pemasaran Islami memiliki posisi yang sangat strategis dikarena pemasaran Islam merupakan salah satu stratehgi pemasaran yang didasarkan pada Al-Qur'an dan sunah Rasulullah Saw. Pemasaran Islami dapat diartikan sebagai kebijaksanaan untuk memenuhi kebutuhan pelanggan melalui perilaku yang baik dalam memberikan produk dan layanan halalan thayyiban, sehat, murni dan sah dengan persetujuan bersama dari penjual dan pembeli untuk tujuan mencapai kemaslahatan serta kesejahteraan material dan spiritual di Dunia dan Akhirat serta membuat konsumen menyadarinya melalui perilaku baik pemasar dan iklan etis. ${ }^{6}$ Pemasaran Islami dijadikan sebagai sebuah disiplin ilmu bisnis strategis yang mengarahkan pada proses penawaran dan permintaan dari satu pemrakarsa kepada stakeholders yang dalam keseluruhan prosesnya sesuai dengan akad prinsip-prinsip Islam dan muamalah.

Dengan ini, pebisnis dapat menyesuaikan diri dengan menyusun Islamic marketing strategy melalui strategi STP (Segmenting, Targetting dan Positioning) untuk menarik konsumen. Marketing strategy merupakan salah satu unsur penting yang harus diperhatikan oleh pebisnis. Hal tersebut berisi segmenting yang memiliki arti sebagai usaha untuk membagi pasar ke dalam kelompok-kelompok yang dapat dibedakan satu sama lain dalam hal kebutuhan, karakteristik, atau perilaku yang mungkin akan memerlukan produk-produk dan strategi pemasaran tertentu untuk menjangkaunya. Pada dasarnya segmentasi pasar merupakan suatu strategi yang didasarkan pada falsafah manajemen pemasaran yang berorientasi pada konsumen. Dengan melaksanakan segmentasi pasar, kegiatan pemasaran dapat dilakukan lebih terarah dan sumber daya perusahaan di bidang pemasaran dapat digunakan secara lebih efektif dan efisien.

Sedangkan targetting adalah proses pengevaluasian segmentasi dan pemfokusan strategi pemasaran pada sebuah sekelompok orang yang memiliki potensi untuk memberikan respon. Target pasar dapat juga diartikan sebagai kegiatan yang berisi dan menilai serta memilih satu atau lebih segmen pasar yang akan dimasuki oleh suatu perusahaan. Selanjutnya positioning mencakup kegiatan merumuskan penempatan produk dalam persaingan dan menetapkan bauran pemasaran yang terperinci. Pada hakikatnya penempatan produk adalah tindakan merancang produk dan bauran pemasaran agar tercipta kesan tertentu di ingatan konsumen. Proses marketing inilah yang memastikan bahwa setiap produk barang dan jasa dari pebisnis bisa sampai kepada konsumen. Oleh karena itu, diperlukan strategi-strategi khusus untuk menjalankan kegiatan marketing dan memastikan bahwa pebisnis mendapatkan keuntungan sesuai dengan yang diharapkan. ${ }^{7}$

5 Wan Laura Hardilawati, "Strategi Bertahan UMKM di Tengah Pandemi Covid-19", Jurnal Akuntansi dan Ekonomika, Vol. 10, No. 1, (Juni, 2020), 89-99.

${ }^{6}$ Institut Tazkia, Tujuh Paket Ekonomi ..., 1-7.

${ }^{7}$ Philip Kotler, Marketing, Jilid 1, (Jakarta: Erlangga, 1987), 2. 
Semakin tidak terkendalinya Covid-19 menyebar, semakin banyak bisnis yang menderita. Alasannya, pebisnis khawatir usaha yang mereka jalani akan terkena imbas krisis. Krisis yang sedang berlangsung telah menekan para pebisnis untuk terus bertahan pada setiap usahanya. Ada sebagian bisnis yang justru meningkat, sedangkan yang lainnya berjuang untuk hanya mendapatkan satu atau dua penjualan. ${ }^{8}$ Meski demikian, kondisi itu bukan berarti menjadikan pebisnis dalam berwirausaha di sektor ekonomi kreatif pada masa pandemi Covid-19 ikut terhambat, termasuk di antaranya dalam mencari peluang usaha. Berwirausaha di sektor ekonomi kreatif telah menjadi primadona tersendiri pada saat ini. Pemerintah menyusun regulasi melalui Peraturan Presiden Nomor 72 Tahun 2015 tentang Perubahan Atas Peraturan Presiden Nomor 6 Tahun 2015 tentang Badan Ekonomi Kreatif. Regulasi tersebut bertujuan untuk merangsang pertumbuhan pada sektor ekonomi kreatif di Indonesia sebagai salah satu sektor ekonomi yang memiliki potensial. ${ }^{9}$

Pengembangan wirausaha di sektor ekonomi kreatif ibarat bahan bakar bagi perusahaan sebagai pemacu untuk untuk tetap eksis dalam memenangi persaingan di era yang sangat kompetitif saat ini. Kemampuan perusahaan untuk bertahan dalam ketatnya persaingan serta mempertahankan product life cycle pada tahapan menanjak ataupun puncak akan sangat dipengaruhi oleh kemampuan perusahaan dan individu di dalamnya untuk berinovasi dan kreatif. Perkembangan pengetahuan dan teknologi secara cepat juga saat ini telah berdampak pada lahirnya peluang usaha baru ataau pun lama yang akan diperbarui di sektor ekonomi kreatif. ${ }^{10}$ Teknologi itu pun saat ini juga memungkinkan hadirnya bisnis baru dengan biaya operasional yang lebih efektif dan efisien. Peluang ini sangat potensial untuk dimanfaatkan dengan baik oleh pebisnis untuk berwirausaha dalam menciptakan berbagai kemampuan dalam mengelola dan mengembangkan barang dan jasa baru di masa-masa seperti ini. ${ }^{11}$

Kemampuan untuk melihat peluang sebelum orang lain juga salah satu aspek penting dalam kegiatan berwirausaha. Seorang pebisnis baru atau pun lama sangat dituntut agar lebih peka dengan segala kemungkinan kondisi yang terjadi terhadap kegiatan usaha mereka dalam lingkungan yang sangat dinamis terutama dalam sektor ekonomi kreatif. Era modern saat ini juga menghadirkan persaingan yang lebih ketat dari era sebelumnya. Persaingan yang seringkali meniadakan batas geografis dan negara sehingga sesuatu yang dihasilkan di suatu negara tidak hanya bersaing dengan produk di negara tersebut namun juga

8 Jurnal Entrepreneur, "7 Strategi Pemasaran Produk Bisnis di Tengah Pandemi Corona", https://www.jurnal.id/id/blog/7-strategi-pemasaran-produk-ukm-saat-krisis-virus-Covid-19/,

diakses pada tanggal 24 Mei 2020.

${ }^{9}$ Peraturan Presiden Nomor 72 Tahun 2015 tentang Perubahan Atas Peraturan Presiden Nomor 6 Tahun 2015 tentang Badan Ekonomi Kreatif.

${ }^{10}$ Yenti Sumarni, "Manajemen Ekonomi Islam dalam Menangani Pandemi Coronavirus Disease (Covid-19) di Indonesia", Jurnal Baabu Al-Ilmi, Vol. 5, No. 1, (April, 2020), 117-127.

${ }^{11}$ W. L. Hardilawati, "Model Pemasaran Hubungan Pelanggan, Inovasi Dan E-Commerce Dalam Meningkatkan Kinerja Pemasaran Ukm Di Pekanbaru”, Jurnal Akuntansi Dan Ekonomika, Vol. 9, No. 2, (2019), 213-222.

el-Qist: Journal of Islamic Economics and Business (JIEB) 
bersaing dengan produk sejenis dari berbagai belahan dunia. ${ }^{12}$ Tantangan inilah yang menjadikan aspek kreativitas dan inovasi sebagai kekuatan utama dalam bisnis terkini. Peran konsep atau design dalam berwirausaha di sektor ekonomi kreatif dianggap sebagai faktor yang berkontribusi positif dalam mendukung kesuksesan pebisnis dalam melakukan kegiatan berwirausaha di sektor ekonomi kreatif. 13

Ini berarti, pebisnis harus memikirkan kembali upaya apa yang dapat dilakukan agar membuat bisnis tetap berjalan. Berikut hasil penelitian mengenai penyusunan strategi pemasaran Islam dalam berwirausaha apa saja yang dapat dilakukan pada masa pandemi Covid-19 dan faktor pendukung dalam berwirausaha di sektor ekonomi kreatif pada masa pandemi Covid-19. Penelitian ini diharapkan menemukan konsep baru dalam strategi pemasaran islami. Di samping itu, unsur-unsur syari'ah yang terkandung sebagai faktor pendukung dalam strategi pemasaran Islami sehingga penelitian ini dapat digunakan untuk memperkaya khasanah ilmu pengetahuan sebagai bahan referensi bagi peneliti yang akan datang.

\section{METODE PENELITIAN}

Metode penelitian ini menggunakan kualitatif dengan pendekatan kepustakaan (library research). Library research yakni penelitian yang dilaksanakan dengan menggunakan literatur, baik berupa buku, catatan, maupun laporan hasil penelitian terdahulu. ${ }^{14}$ Dalam penelitian ini peneliti menitikberatkan pada hasil-hasil pengumpulan data yang didapatkan dengan menggunakan jenis dan sumber data sekunder yang diperoleh dari hasil penelitian, artikel dan buku-buku referensi yang membahas topik yang berkaitan dengan tema penelitian. ${ }^{15}$ Pembahasan tentang strategi pemasaran telah banyak dibahas sebagai karya ilmiah. Untuk mendukung persoalan yang lebih mendalam terhadap masalah di atas, peneliti berusaha melakukan penelitian terhadap kajian literatur yang relevan terhadap masalah yang menjadi obyek penelitian. Hasil kajian literatur digunakan untuk mendeskripsikan strategi pemasaran Islam pada fenomena kewirausahaan di sektor ekonomi kreatif pada masa pandemi Covid-19. Sedang analisis data bersifat deskriptif, karena penelitian ini menggambarkan dan menguraikan secara objektif hal-hal yang berkaitan dengan penyusunan strategi pemasaran Islam dalam berwirausaha di sektor ekonomi kreatif pada masa pandemi Covid-19.

12 N. Betz, \& G. Hackett, "The relationship of career-related self-efficacy expectations to perceived career options in college men and women", Journal of Counseling Psychology, Vol. 2 No. 8, (1981), 399-410.

${ }^{13}$ Mirdha Fahlevi dan Yusnaidi, "Entrepreneurial Leadership, Self Effcicacy, Inovasi dan Modal Sosial dalam Berwirausaha di Sektor Ekonomi Kreatif", Jurnal Bisnis dan Kajian Strategi Manajemen, Vol. 4, No. 1, (2020), 13-29.

${ }^{14}$ Lexi J Moleong, Metodologi Penelitian Kualitatif, (Bandung: PT Remaja Rosdakarya, 2013), 6.

${ }^{15}$ Sugiyono, Metode Penelitian Kuantitatif, Kualitatif dan R\&D, (Bandung: Alfabeta, 2019), 112. el-Qisț: Journal of Islamic Economics and Business (JIEB) 


\section{STRATEGI PEMASARAN}

Strategi pemasaran adalah serangkaian tujuan dan sasaran, kebijakan dan aturan yang memberikan arahan kepada usaha-usaha pemasaran dari waktu ke waktu, pada masing-masing tingkatan dan acuan serta alokasinya, terutama sebagai tanggapan perusahaan organisasi/bisnis dalam menghadapi lingkungan dan keadaan pesaing yang selalu berubah. ${ }^{16}$ Strategi pemasaran bisa mengenai strategi spesifik untuk pasar sasaran, penetapan posisi, bauran pemasaran dan pengembangan pemasaran dalam keunggulan bersaing. ${ }^{17}$

\section{A. Marketing Strategy}

Strategi pemasaran terdapat dasar tindakan yang mengarah pada kegiatan perusahaan organisai/bisnis, kondisi persaingan dan lingkungan yang bisa selalu berubah-ubah dengan harapan dapat tercapainya suatu tujuan yang diinginkan. Sebelum strategi pemasaran dipakai, harus dilihat terlebih dulu kondisi pasar sekaligus menilai posisi pasar tersebut supaya dapat ditentukan kegiatan pemasaran apa saja yang pas untuk diterapkan. ${ }^{18}$ Berikut strateginya: 19

\section{Segmentation}

Segmentasi pasar yakni tindakan mengidentifikasi dan membentuk kelompok pembeli atau konsumen secara terpisah. Masing-masing konsumen dibedakan menurut karakteristik kebutuhan produk dan bauran pemasaran tersendiri.

\section{Targeting}

Target pasar, yakni tindakan memilih satu atau lebih segmen pasar yang akan dimasuki. Dalam target pasar terdapat beberapa segmen diantaranya tingkat permintaan/pertumbuhan pasar, daya tarik konsumen dalam jangka panjang dan sasaran sumber daya kompetitor.

3. Positioning

Posisi pasar, yakni menetapkan posisi pasar, tujuannya adalah untuk membangun dan mengkomunikasikan keunggulan bersaing produk yang ada dipasar ke dalam benak konsumen. Strategi penentuan posisi pasar terdiri atas dasar atribut (harga murah atau harga mahal), menurut kelas pengguna atau pun menurut kelas produk.

\section{B. Marketing Tactic}

Sebuah strategi atau langkah-langkah sebagai tak tik untuk meningkatkan produk agar banyak diminati oleh konsumen mencapai winning market share, yang dapat ditempu melalui cara sebagai berikut: ${ }^{20}$

\section{Product Differentiation}

Diferensiasi produk adalah proses pembedaan suatu produk atau jasa untuk membuatnya lebih menarik terhadap suatu pasar sasaran tertentu.

\footnotetext{
${ }_{17}^{16}$ John A. Pearce, Richard B. Robinson, Manajemen Strategi, (Jakarta: Salemba Empat, 2014), 4.

17 Plilip Kotler, Manajemen Pemasaran, Edisi Mileinium, (Jakarta: PT. Indeks Kelompok Gramedia, 2000), 48.

18 Noviadry Nur Tamtama, Peran Relationship Marketing dalam Menciptakan Loyalitas Pelanggan, (Tesis - Universitas Muhammadiyah Surakarta, 2017), 4.

${ }^{19}$ Fandy Tjiptono, Strategi Pemasaran, (Yogyakarta: ANDI Offset, 2018), 24.

${ }^{20}$ Basu Swasatha dan Irawan, Manajemen Pemasaran Modern ..., 349. el-Qisț: Journal of Islamic Economics and Business (JIEB) 
Pembedaan tersebut dilakukan baik terhadap produk kompetitor maupun terhadap produk lain dari produsen produk itu sendiri.

2. $7 \mathrm{P}$

Strategi pemasaran selanjutnya yang dapat menentukan kesuksesan perusahaan dalam mengejar profit atau keuntungan maksimal yakni dengan menggunakan konsep $7 \mathrm{P}$, yaitu products, price, promotions, place, people, process dan physical evidence. Konsep ini tentunya berbeda dengan $4 \mathrm{P}$ yang hanya memiliki empat konsep, yaitu product, place, price dan promotion. Pada $4 \mathrm{P}$, empat konsep yang digunakan terkesan product oriented saja.

3. Personal Selling

Penjualan perorangan adalah komunikasi langsung (tatap muka) antara penjual dan calon pelanggan untuk memperkenalkan suatu produk kepada calon pelanggan dan membentuk pemahaman pelanggan terhadap produk sehingga mereka kemudian akan mencoba membelinya.

C. Marketing Value

Nilai pasar menjadi sebuah paradigma pemasaran yang banyak diterapkan oleh perusahaan organisasi/bisnis, baik perusahaan manufakturing maupun perusahaan jasa, untuk memenangkan persaingan merebut pasar konsumen. Nilai pasar yang dibangun adalah sebagai berikut: ${ }^{21}$

1. Brand

Merek adalah suatu nama, simbol, tanda, desain atau gabungan di antaranya untuk dipakai sebagai identitas perorangan, organisasi atau perusahaan suatu bisnis pada barang dan jasa yang dimiliki untuk membedakan dengan produk lainnya.

2. Services

Pelayanan diberikan sebagai tindakan atau perbuatan seseorang atau organisasi suatu bisnis untuk memberikan kepuasan kepada konsumen. Tindakan yang dilakukan guna memenuhi kebutuhan konsumen akan suatu produk atau jasa yang mereka butuhkan.

3. Process

Proses menyangkut kemampuan suatu perusahaan dalam produksi untuk melakukan tindakan sesuai dengan apa yang diharapkan atau ditetapkan perusahaan serta kemampuan untuk melakukan penyaluran hasil produksi yakni distribusi hingga sampai konsumsi.

\section{EKONOMI KREATIF}

Ekonomi kreatif adalah sebuah konsep di era ekonomi baru yang mengintensifkan informasi dan kreativitas dengan mengandalkan ide dan pengetahuan dari sumber daya manusia sebagai faktor produksi yang utama. Konsep ini biasanya akan didukung dengan keberadaan industri kreatif yang menjadi pengejawantahannya. ${ }^{22}$ Konsep di antaranya adalah:

${ }^{21}$ Kasmir, Etika Customer Service, (Jakarta: PT RajaGrafindo Persada, 2005), 81-86.

${ }^{22}$ Carunia Mulya Firdausy, Strategi Pengembangan Ekonomi Kreatif di Indonesia, (Jakarta: Yayasan Pustaka Obor Indonesia, 2017), 20. el-Qisț: Journal of Islamic Economics and Business (JIEB) 


\section{A. Promotion}

Promosi adalah suatu bentuk komunikasi pemasaran. Yang dimaksud komunikasi pemasaran adalah aktivitas pemasaran yang berusaha menyebarkan informasi, mempengaruhi atau membujuk, dan mengingatkan pasar sasaran atas produknya agar bersedia menerima, membeli, dan loyal pada produk yang ditawarkan perusahaan yang bersangkutan. ${ }^{23}$

B. Service Excellent

Pelayanan prima adalah pelayanan yang memenuhi standar kualitas yang sesuai dengan harapan dan kepuasan pelanggan. Di dunia bisnis, persaingan antar pebisnis sangat ketat. Hal inilah yang kemudian mengakibatkan para penjual harus memberikan servis yang memuaskan kepada para pelanggannya, karena jika tidak maka para pelanggannya akan beralih. ${ }^{24}$

C. Customers Rewards

Pemberian hadiah atau reward merupakan salah satu strategi pemasaran dalam berbisnis. Tujuannya adalah untuk mempertahankan kesetiaan pelanggan atau konsumen, sebagai daya tarik untuk mendapatkan konsumen, meningkatkan omset usaha, sebagai media promosi dan sebagai wujud rasa terima kasih. Terdapat banyak jenis benda atau barang yang bisa digunakan sebagai hadiah atau reward sebagai sarana pengenalan produk pula kepada para konsumen. ${ }^{25}$

D. Afiliasi atau Kemitraan

Kemitraan bisnis adalah kontrak di antara para mitra perusahaan di mana syarat dan ketentuan kemitraan dinyatakan secara jelas termasuk rasio bagi hasil, kewajiban, aset, investasi, dan lainnya. Dengan kemitraan, bisnis terbukti lebih tahan lama dan menghasilkan efisiensi serta sumber daya yang dimiliki pihak-pihak yang bermitra karenanya menguntungkan semua pihak. ${ }^{26}$

E. Modal Sosial

Modal sosial adalah merupakan hubungan-hubungan yang tercipta dan norma-norma yang membentuk kualitas dan kuantitas hubungan sosial dalam masyarakat dalam spectrum yang luas, yaitu sebagai perekat sosial (social glue) yang menjaga kesatuan anggota masyarakat (bangsa) secara bersamasama. Modal sosial ditransmisikan melalui mekanisme-mekanisme kultural, seperti agama, tradisi, atau kebiasaan sejarah. ${ }^{27}$

${ }^{23}$ Fandy Tjiptono, Strategi Pemasaran, edisi ke-2, (Yogyakarta: ANDI Offset, 2001), 219.

${ }^{24}$ Veithzal Rivai, dkk, Islamic Business and Economic Ethics, (Jakarta: Bumi Aksara, 2012), 3.

${ }^{25}$ Mufti Alam Adha, Rofiul Wahyudi, Faiza Husnayeni Nahar, "Pengaruh Program Loyalitas terhadap Kesetiaan Konsumen pada Industri Halal di Yogyakarta", Jurnal Ihtifaz: Islamic Economics, Finance and Banking, Vol. 1, No. 1, (Juni, 2018), 69-88.

${ }^{26}$ I Dewa Nyoman Arta Jiwa, "Relationship Marketing, Power dan Loyalitas pada Hubungan Bisnis", Jurnal Mitra Manajemen, Vol. 2, No. 3, (2018), 115-251.

${ }^{27}$ Rusydan Fathy, "Modal Sosial: Konsep, Inklusivitas dan Pemberdayaan Masyarakat", Jurnal Pemikiran Sosiologi, Vol. 6, No. 1, (2019), 1-17. el-Qisț: Journal of Islamic Economics and Business (JIEB) 


\section{PENYUSUNAN STRATEGI PEMASARAN ISLAM DALAM BERWIRAUSAHA DI SEKTOR EKONOMI KREATIF PADA MASA PANDEMI COVID-19}

Munculnya himbauan dan peraturah pemerintah untuk tidak keluar rumah, tentu saja berpengaruh terhadap banyak hal termasuk Usaha Mikro Kecil Menengah (UMKM). Pemerintah melalui situs resmi Kementrian Koperasi dan UMKM menyatakan penyebaran Covid-19 berpotensi berdampak secara langsung terhadap ekonomi termasuk keberlangsungan koperasi, usaha mikro, kecil dan menengah (KUMKM). ${ }^{28}$ Kini Kementrian Koperasi dan UMKM tengah mendata kondisi UMKM yang mengalami kesulitan bahan baku, kendala proses produksi dan permintaan pasar yang turun drastis dan kemudian memetakan dampak Covid-19 ini terhadap UMKM. Rata-rata UMKM merasakan penurunan omset selama adanya Covid-19. Hal ini terjadi karena mulai berkurangnya aktivitas yang dilakukan di luar rumah, kesulitan dalam memperoleh bahan baku karena terjadi kendala transportasi, serta mulai turunnya kepercayaan masyarakat terhadap produk yang ada di luar terutama bidang kuliner. UMKM yang merupakan salah satu penopang perekonomian karena juga banyak menyediakan lapangan pekerjaan, dengan adanya Covid-19 ini, juga mulai ada yang melakukan putus hubungan kerja (PHK) atau merumahkan karyawan sementara karena perusahaan/usaha mereka harus tutup sementara waktu atau sebab hanya 50\% kapasitas karyawana saja yang boleh masuk kerja. ${ }^{29}$

Meskipun pandemi Covid-19 di Indonesia belum mereda, namun nyatanya tidak semua UMKM merasakan penurunan omset penjualan dan harus menutup usahanya, ada UMKM yang masih stabil dan mengalami peningkatan omset penjualannya karena mereka melakukan penyesuaian diri dalam hal produk dan melakukan beberapa strategi pemasaran untuk bertahan. ${ }^{30}$ Strategi pemasaran adalah serangkaian tujuan dan sasaran, kebijakan dan aturan yang memberikan arahan kepada usaha-usaha pemasaran dari waktu ke waktu, pada masing-masing tingkatan dan acuan serta alokasinya, terutama sebagai tanggapan perusahaan organisasi/bisnis dalam menghadapi lingkungan dan keadaan pesaing yang selalu berubah. ${ }^{31}$ Strategi pemasaran bisa mengenai strategi spesifik untuk pasar sasaran, penetapan posisi, bauran pemasaran dan pengembangan pemasaran dalam keunggulan bersaing. ${ }^{32}$

Menurut ajaran Islam, strategi pemasaran dalam kegiatan pemasar harus dilandasi dengan nilai-nilai Islami yang dijiwai oleh semangat ibadah kepada Allah swt. dan berusaha semaksimal mungkin guna kemaslahatan umat dan kesejahteraan bersama, bukan hanya untuk kepentingan golongan apalagi kepentingan pribadi. Istilah pemasaran tidak banyak dikenal pada masa Nabi saw. Saat itu konsep yang banyak dikenal adalah jual beli (bai') yang memang

28 Kementerian Koperasi dan Usaha Kecil dan Menengah, Siaran Pers, http://www.depkop.go.id/siaran-pers, diakses pada tanggal 18 Juni 2020.

${ }^{29}$ Wan Laura Hardilawati, "Strategi Bertahan UMKM ..., 89-99.

${ }^{30}$ Azwar Iskandar, Bayu Taufiq Possumah, Khaerul Akbar, "Peran Ekonomi ..., 625-638.

31 John A. Pearce, Richard B. Robinson, Manajemen Strategi ..., 4.

${ }^{32}$ Plilip Kotler, Manajemen Pemasaran ..., 48. el-Qisț: Journal of Islamic Economics and Business (JIEB) 
sudah ada sebelum Islam datang. Pemasaran dapat dilakukan melalui komunikasi dan silahturahmi dalam rangka untuk memperkenalkan produk atau barang dagangan. Dalam Hadis Nabi saw. riwayat Anas ibn Malik ra. yang disampaikan oleh al-Bukhari dalam kitab Saḥịnnya:

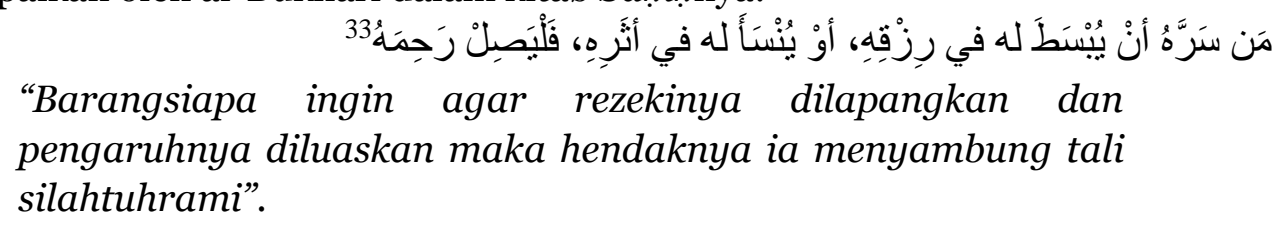

Dari Hadis tersebut dapat disimpulkan bahwa dalam kegiatan pemasaran juga melakukan silahtuhrami sesama manusia. Menjaga silahturahmi sesama manusia adalah hal yang wajib. Karena dalam pemasaran tentunya akan bertemu dengan orang banyak, semakin banyak relasi yang dikenal akan semakin memperpanjang tali silahturahmi. Maka dari itu sebaiknya senantiasa untuk selalu menjaga tali silahturahmi sesama manusia. 34

Ada beberapa hal yang dapat dilakukan oleh UMKM selaku pebisnis termasuk memilih membuka lini produk baru atau memperbaharui sistem pemasaran mereka, karena bisnis yang mampu bertahan adalah bisnis yang resposif terhadap perubahan lingkungan persaingan bisnis mereka. Dalam konteks bisnis di sektor ekonomi kreatif, para pebisnis sangat dituntut mempunyai kemampuan marketing dalam mengelola dan mengembangkan bisnisnya. Persaingan bisnis bisa berarti persaingan memperebutkan konsumen. Persaingan bisnis yang semakin ketat telah mendorong perusahaan untuk melakukan pengamatan melalui perilaku konsumen dalam meningkatkan strategi pemasarannya. Dengan menciptakan pasar ekonomi adalah sesuatu yang mutlak dan sangat penting dalam berbisnis. Sebagus apapun produk yang diproduksi tidak akan ada artinya bila tidak bisa memiliki pasar. Maka dari itu, pebisnis harus menciptakan pasar yang mampu memberi keuntungan. 35 Adapun beberapa hal penyusunan strategi pemasaran Islam dalam berwirausaha apa saja yang dapat dilakukan pada masa pandemi Covid-19 yang bisa dilakukan oleh para pebisnis dalam berwirausaha di antaranya marketing strategy melalui strategi STP (Segmenting, Targetting dan Positioning) untuk menarik konsumen. Marketing merupakan salah satu hal penting yang harus dilakukan ketika menjalankan sebuah usaha, baik usaha baru maupun usaha lama yang telah dirintis bertahun-tahun lamanya. Sebelum menjalankan marketing, pertama kali yang harus dilakukan adalah menentukan konsep marketing serta strategi pemasaran yang efektif dalam menjual produk barang dan jasa. ${ }^{36}$ Dengan banyaknya UMKM yang bermunculan dan terdesaknya pandemi Covid-19 saat ini, maka perlu adanya strategi pemasaran yang tepat agar dapat menarik minat

\footnotetext{
${ }^{33}$ Ahmad b. Ali b. Hajar al-Asqalani, Fatḥ al-Bāri Sharḥ al-Saḥịh al-Bukhārī Vol. 10 No. Hadis 5639 (Kairo: Dār al-Rayyān li al-Turāth, 1986), 429.

${ }^{34}$ Idri, Hadis Ekonomi, (Jakarta: Kencana, 2015), 192.

35 Hawangga Dhiyaul Fadly, Sutama, "Membangun Pemasaran Online dan Digital Branding Ditengah Pandemi Covid-19”, Jurnal Ecoment Global, Vol. 5, No. 2, (Agustus, 2020), 213, 223.

${ }^{36}$ Fandi Tjiptono, Pemasaran Jasa, (Yogyakarta: Andi Offset, 2014), 4. el-Qisț: Journal of Islamic Economics and Business (JIEB) 
para konsumen. Meskipun sulit, namun jika fokus dalam merencanakan strategi pemasaran tersebut, maka bukan tidak mungkin usaha kecil pun dapat tumbuh berkembang menjadi besar.

Pada umumnya, usaha kecil mempunyai anggaran marketing yang terbilang kecil jika dibandingkan dengan usaha berskala besar. Dengan anggaran yang minim tersebut tentunya harus lebih kreatif dalam menentukan strategi pemasaran yang tepat. Strategi pemasaran terdapat dasar tindakan yang mengarah pada kegiatan perusahaan organisai/bisnis, kondisi persaingan dan lingkungan yang bisa selalu berubah-ubah dengan harapan dapat tercapainya suatu tujuan yang diinginkan. Sebelum strategi pemasaran dipakai, harus dilihat terlebih dulu kondisi pasar sekaligus menilai posisi pasar tersebut supaya dapat ditentukan kegiatan pemasaran apa saja yang pas untuk diterapkan. ${ }^{37}$ Dalam rangkaian proses strategi pemasaran, segmentation, targeting dan positioning berada di tahap awal yang paling penting yakni mengidentifikasi customer value atau nilai dari pelanggan. STP berada di level strategi karena menentukan bagaimana menggarap pasar. ${ }^{38}$ Segmenting adalah proses mengelompokkan dan membagi-bagi beberapa segmen pasar menurut kelompok pasar tertentu. Tujuan dari segmentasi pasar adalah untuk menempatkan produk sesuai dengan karakter masing-masing pasar agar tepat pada sasaran. Segmentasi pasar juga dimaksudkan untuk mengidentifikasi kelas-kelas dalam masyarakat yang mempunyai perbedaan kebutuhan dan keinginan akan produk perusahaan. Sehingga dengan segmentasi tersebut pasar yang heterogen dapat dibagi-bagi dalam beberapa segmen pasar yang bersifat homogen. 39

Dasar-dasar yang dapat dipakai untuk segmentasi pasar yang dapat dilakukan pada masa pandemi Covid-19 adalah faktor demografi, seperti umur, kepadatan penduduk, jenis kelamin, agama, kesukuan, pendidikan dan sebagainya melalui data-data Pemerintah yang telah terakuisisi. Kemudian faktor sosiologis, seperti kelompok budaya, kelas-kelas sosial dan sebagainya yang bisa kita observasi dilingkungan usaha. Lalu faktor psikologis/psikografis, seperti sikap, kepribadian, manfaat produk yang diinginkan dan sebagainya dari hasil perilaku konsumen. Selanjutnya faktor geografis, seperti daerah sejuk, pantai, daerah kota, daerah desa dan sebagainya yang bisa dikondisikan. Serta tingkat penghasilan calon-calon konsumen. $4^{\circ}$ Kemudian terdapat tiga jenis segmen pasar sasaran produk dalam halal market, yaitu Halal Activist, Active Customers, dan Passive Customers yang masing-masing memiliki tingkat pembelian yang berbeda. Halal Activist merupakan kelompok yang tidak hanya concern terhadap produk halal bagi diri mereka sendiri, namun bagi orang lain. Segmen ini memiliki seluruh pola pembelian 5A (Aware, Appeal, Ask, Act, dan Advocate). Ini berarti, konsumen sampai pada tahap memberikan advokasi terhadap produk yang ia gunakan kepada calon konsumen yang bertanya mengenai produk

\footnotetext{
${ }^{37}$ Noviadry Nur Tamtama, Peran Relationship Marketing ..., 4.

${ }^{38}$ Sofian Assauri, Manajemen Pemasaran: Dasar, Konsep \& Strategi, cet. Ke-1, ed. 1, (Jakarta: RajaGrafindo Persada, 2011), 198.

${ }^{39}$ Sofian Assauri, Manajemen Pemasaran, (Jakarta: Rajawali Pers, 1992), 2.

${ }^{40}$ Thamrin Abdullah, Francis Tantri, Manajemen Pemasaran, (Jakarta: Rajawali Pers, 2016), 21. el-Qisț: Journal of Islamic Economics and Business (JIEB) 
tersebut. Sementara, Active Customers terdiri dari kelompok yang umumnya menggunakan standar awal bagi diri mereka sendiri. Segmen ini berakhir pada tahap action. Active Customers umumnya secara aktif bertanya mengenai produk yang akan mereka gunakan. Kegiatan bertanya saat ini sudah menjadi trend, bahkan hanya menulis status bertanya atau meminta rekomendasi di media sosial pun dapat masuk ke dalam kategori tersebut. Berbeda dengan Active Customers, Passive Customers hanya melalui pola aware, appeal, action dan advocate. Passive Customers tidak melalui pola ask ataupun advocate. Mereka cenderung bergerak pasif. ${ }^{41}$

Setelah perusahaan mengidentifikasi peluang segmen pasar, selanjutnya adalah mengevaluasi beragam segmen tersebut untuk memutuskan segmen mana yang menjadi target market. Target market adalah sekumpulan nasabah yang dituju yang akan dilayani dengan program pemasaran tertenu. Pasar sasaran atau market targeting terdiri dari sekumpulan pembeli yang mempuyai kebutuhan atau karakter yang sama, yang ingin dilayani oleh perusahaan. Targeting merupakan kegiatan memilih dan menilai satu atau lebih segmen pasar yang akan dimasuki. Tujuan dari penentuan target ini adalah memberikan kepuasan bagi konsumen. Ketika konsumen puas, maka permintaan produk tersebut semakin meningkat, dengan meningkatnya permintaan maka keuntungan perusahaan pun juga mengalami peningkatan. Produk dari targeting adalah target market (pasar sasaran), yaitu satu atau segmen pasar yang akan menjadi fokus kegiatan-kegiatan marketing. Perusahaan dapat mempertimbangkan lima pola pemilihan pasar sasaran, yaitu konsentrasi pada segmen tunggal (single segment concentrattion), spesialisasi terpilih (selective specialization), pesialisasi pasar (market specialization), spesialisasi produk (product specialization) dan angkauan pemasaran penuh (full market coverage). ${ }^{2}$ Dalam masalah yang paling mudah, perusahaan memilih sebuah segmen tunggal. Hal ini dilakukan karena adanya keterbatasan dana yang dimiliki perusahaan, adanya peluang pasar dalam segmen bersangkutan yang belum digarap atau bahkan diabaikan oleh pesaing, atau perusahaan menganggap segmen tersebut merupakan segmen yang paling tepat. Melalui keputusan berkonsentrasi pada hanya satu segmen, perusahaan mendapatkan pemahaman mendalam mengenai kebutuhan segmen bersangkutan dan bisa mewujudkan posisi pasar dan citra merk yang kuat. Selanjutnya perusahaan memilih sejumlah segmen pasar yang menarik dan sesuai dengan tujuan dan sumber daya yang dimiliki.

Masing-masing segmen bisa memiliki sinergi kuat satu sama lain maupun tanpa sinergi sama sekali, namun paling tidak setiap segmen menjanjikan sumber penghasilan bagi perusahaan. Dengan strategi ini perusahaan dapat melakukan penyebaran resiko, dimana jika terjadi penurunan pada salah satu segmen, maka penjualan perusahaan secara keseluruhan tidak terlalu berpengaruh, karena tetap memperoleh pendapatan dari segmen lain. Kemudian

\footnotetext{
${ }^{41}$ Marketeers, "Segmentasi Pasar halal", https://www.marketeers.com/kenali-segmen-pasar-halalsebelum-masuki-marketnya/, diakses pada tanggal 12 Juni 2020.

${ }^{42}$ Hari Wijaya \& Hani Sirine, "Strategi Segmenting, Targeting, Positioning serta Strategi Harga", Asian Journal of Innovation and Entrepreneurship, Vol. 1, No. 3, (September 2016), 175-191.
} el-Qisț: Journal of Islamic Economics and Business (JIEB) 
perusahaan berkonsentrasi untuk melayani banyak kebutuhan dari suatu kelompok pelanggan tertentu. Melalui strategi ini, perusahaan memperoleh reputasi yang kuat dalam melayani kelompok pelanggan tersebut dan menjadi acuan pokok bagi pelanggan bersangkutan jika kelak pelanggan tersebut membutuhkan produk lainnya. Serta perusahaan akan berkonsentrasi pada pembuatan produk tertentu yang dijual di beberapa segmen. Melalui strategi ini, perusahaan memperoleh reputasi yang kuat dalam bidang produk spesifik. Sehingga perusahaan berusaha untuk melayani semua produk pelanggan dengan semua produk yang diperlukan. Hanya perusahaan-perusahaan besar yang dapat menangani suatu strategi jangkaun pasar secara penuh. Apabila target pasar (sasaran program) sudah jelas, selanjutnya yakni positioning.

Positioning adalah tindakan merancang produk dan citra perusahaan agar dapat tercipta kesan atau tempat khusus dan unik dalam benak pasar sasaran sedemikian rupa, sehingga dipersepsikan lebih unggul dibanding kan para pesaingnya. 43 Product positioning merupakan suatu strategi menejemen yang mengunakan informasi untuk menciptakan suatu kesan terhadap produk sesuai dengan keinginan pasar yang dituju atau pasarnya. Jadi, positioning merupakan suatu usaha yang dilakukan oleh perusahaan dalam mendesain produk-produk mereka sehingga dapat menciptakan kesan dan image tersendiri dalam pikiran konsumennya sesuai dengan yang diharapkan ntuk menentukan positioning perlu dilakukan strategi yang benar, sehingga posisi pasar yang diinginkan tepat pada sasarannya. Strategi penentuan posisi produk meliputi positioning menurut manfaat, kategori, atribut dan nilainya. Penentuan posisi menurut manfaat adalah memposisikan produk sebagai pemimpin dalam suatu manfaat tertentu. Manfaat mencakup manfaat simbolis, manfaat fungsional dan manfaat berdasarkan pengalaman. ${ }^{4}$

Penentuan posisi yang sukses membutuhkan strategi komunikasi yang mampu menarik perhatian pada salah satu kebutuhan pelanggan, baik simbolis, fungsional maupun eksperimen. Kemudian penentuan posisi menurut kategori produk adalah memposisikan produk sebagai pemimpin dalam kategori produk. Kategori produk dapat kita kelompokkan dalam kategori minuman dan makanan, kategori, produk rumah tangga, kategori obat-obatan, kategori perawatan pribadi, kategori perlengkapan pribadi, kategori perlengkapan rumah, kategori komunikasi dan teknologi informasi, kategori otomotif, kategori perbankan dan keuangan. Lalu penentuan posisi berdasarkan atribut adalah memposisikan produk berdasarkan atribut atau sifat, misalnya simbol, lambang, ukuran, warna, keberadaan, kedudukan dan sebagainya. Dan yang terakhir positioning menurut nilainya adalah pembidikan pasar menentukan pesaing perusahaan. 45 Perusahaan harus meneliti posisi pesaing dan memutuskan posisinya yang

\footnotetext{
${ }^{43}$ Fandy Tjiptono, Strategi Pemasaran ..., 24.

${ }^{44}$ Heriyadi, "Strategi Positioning dalam Persaingan Bisnis", Asian Journal of Innovation and Entrepreneurship, Vol. 3, No. 3, (September 2018), 261-272.

45 Jurnal Entrepreneur, "Strategi Pemasaran Produk Bisnis di Tengah Pandemi Corona", https://www.jurnal.id/id/blog/7-strategi-pemasaran-produk-ukm-saat-krisis-virus-Covid-19/, diakses pada tanggal Juni 2020. el-Qisț: Journal of Islamic Economics and Business (JIEB) 
terbaik. Penentuan posisi (positioning) adalah tindakan untuk merancang citra perusahaan serta nilai yang ditawarkan sehingga pelanggan dalam suatu segmen memahami dan menghargai kedudukan perusahaan dalam kaitannya dengan produk yang dihasilkan.

Sejatinya penerapan strategi pemasaran STP (Segmenting, Targeting dan Positioning) dalam berwirausaha di sektor ekonomi kreatif pada masa pandemi Covid-19 memiliki faktor pendukung. Ekonomi kreatif adalah sebuah konsep di era ekonomi baru yang mengintensifkan informasi dan kreativitas dengan mengandalkan ide dan pengetahuan dari sumber daya manusia sebagai faktor produksi yang utama. Sedangkan faktor pendukung diantaranya adalah konsep promotion, service excellet customers rewards, afiliasi atau kemitraan dan modal sosial. Konsep promosi (promotion) adalah suatu bentuk komunikasi pemasaran. Yang di maksud komunikasi pemasaran adalah aktivitas pemasaran yang berusaha menyebarkan informasi, mempengaruhi atau membujuk, dan mengingatkan pasar sasaran atas produknya agar bersedia menerima, membeli, dan loyal pada produk yang ditawarkan perusahaan yang bersangkutan. ${ }^{6}$ Promosi dapat dilakukan dimulai dari obrolan teman atau keluarga, dari media cetak, dari papan reklame atau papan billboard di jalan, dari radio, dari televisi, dari internet, dan masih banyak lagi. Dalam praktiknya promosi dilakukan berdasarkan pada tujuan-tujuannya diantaranya adalah promosi berusaha untuk merubah tingkah laku dan pendapatan serta memperkuat tingkah laku yang ada. Penjualan (sebagai sumber) selalu menciptakan kesan baik tentang dirinya (promosi kelembagaan) atau mendorong pembelian barang dan jasa perusahaan. ${ }^{47}$ Kegiatan promosi juga dapat ditujukan untuk memberitahu pasar yang dituju tentang penawaran perusahaan. Promosi yang bersifat informatif ini penting bagi konsumen karena dapat membantu dalam pengambilan keputusan untuk membeli. Promosi yang bersifat membujuk diarahkan untuk mendorong keputusan pembelian tidak ingin memperoleh tanggapan secepatnya tetapi lebih mengutamakan untuk menciptakan kesan positif. Hal ini dimaksudkan agar dapat memberi pengaruh dalam waktu yang lama terhadap perilaku pembeli. Promosi juga dilakukan terutama untuk mempertahankan merek produk dihati masyarakat. Ini berarti perusahaan juga berusaha untuk mempertahankan pembeli yang ada.

Selain promosi terdapat pelayanan prima (service excellent) yakni pelayanan yang memenuhi standar kualitas yang sesuai dengan harapan dan kepuasan pelanggan. Di dunia bisnis, persaingan antar pebisnis sangat ketat. Hal inilah yang kemudian mengakibatkan para penjual harus memberikan servis yang memuaskan kepada para pelanggannya, karena jika tidak maka para pelanggannya akan beralih. ${ }^{48}$ Banyak faktor yang perlu dipertimbangkan dalam meningkatkan pelayanan prima, diantaranya adalah arti penampilan secara keseluruhan yang mulai dari cara berpakaian, berbicara, gerak gerik, sikap dan

${ }^{46}$ Fandy Tjiptono, Strategi Pemasaran ..., 219.

47 Ramsiah Tasruddin, "Strategi Promosi Yang Efektif”, Jurnal Al-Khitabah, Vol. II, No. 1, (Desember, 2015), 107 - 116.

${ }^{48}$ Veithzal Rivai, dkk, Islamic Business ..., 3.

el-Qisț: Journal of Islamic Economics and Business (JIEB) 
perilaku dapat membuat pelanggan terkesan. Penampilan pebisnis juga harus selalu terlihat senang dan gembira termasuk pada saat berhubungan dengan pelanggannya. Penampilan ini harus selalu dijaga selama jam kerja secara prima. Kemudian sikap dari perilaku sehari-hari yang ditunjukkan kepada pelanggan pada saat pembelian yang berhubungan dengan pelanggan atau pada saat berada dalam satu ruangan dengan pelanggan. ${ }^{49}$ Pelanggan seringkali memperhatikan sikap dan perilaku ini, baik sengaja atau tidak, terutama sikap yang mau menolong dari peduli terhadap kebutuhan pelanggan. Pelayanan yang prima merupakan langkah strategis yang perlu dilakukan untuk menjaga eksistensi dan loyalitas konsumen. Pada tahap awal pelayanan yang baik dapat akan menumbuhkan kepercayaan konsumen terhadap produsen.

Pebisnis yang baik juga harus bertanggung jawab kepada setiap pelanggan sejak awal hingga selesai. Artinya, dalam menjalankan kegiatan pelayanan, pebisnis harus mampu melayani dari awal hingga akhir konsumen dalam melakukan kegiatan pembelian. Pelanggan akan merasa puas jika petugas bertanggung jawab terhadap pelayanan yang diinginkannya. Jika terjadi sesuatu, pebisnis yang dari awal mengerjakan segera mengambil alih tanggung jawabnya. Dan dalam melayani pelanggan hal lain yang juga penting diperhatiakan adalah sarana dan prasarana yang dimiliki oleh perusahaan. Meja dan kursi serta peralatan pendukung lainnya harus nyaman untuk ditempati dan dipandangi. Kelengkapan dan kenyamanan sarana dan prasarana ini akan membuat pelanggan merasa nyaman dalam lingkungan usaha.50 Kemudian faktor pendukung lainnya adalah customers rewards yang biasa disebut dengan pemberian hadiah atau reward merupakan salah satu strategi dalam marketing bisnis. Tujuannya adalah untuk mempertahankan kesetiaan pelanggan, sebagai daya tarik untuk menjaring konsumen baru, meningkatkan omzet usaha, sebagai wujud rasa terima kasih, dan sekaligus juga sebagai media promosi usaha. Ada banyak jenis benda atau barang yang bisa digunakan sebagai hadiah atau reward untuk para konsumen..$^{1}$

Membangun penghargaan bagi pelanggan menjadi bagian penting dalam strategi pemasaran karena hal tersebut sebagai bentuk apresiasi dalam tahap utama untuk merebut hati pelanggan. Pelanggan merupakan orang yang sangat penting bagi perusahaan..$^{2}$ Karena tanpa pelanggan, penjualan produk tidak akan berhasil sehingga perputaran keuangan perusahaan pun tidak berjalan. Reward bagi konsumen bisa berupa potongan harga atau bonus produk. Bonus dan potongan harga dapat diberikan kepada konsumen yang loyal terhadap produk yang dihasilkan produsen. Pemberian bonus akan menjaga loyalitas konsumen untuk membeli. Selain itu pemberian bonus, khususnya bonus berupa produk baru sangat baik untuk promosi produk tersebut. Pada tahap ini, pelanggan tidak sekadar memperoleh informasi maupun janji-janji seperti dalam iklan, tetapi pelanggan merasakan dan mengalami sendiri keterlibatan dengan produk

${ }^{49}$ Basu Swastha Darmesta, Manajemen Pemasaran Modern, (Yogyakarta: Liberty, 2002), 21.

50 A.A. Barata, Dasar-dasar Pelayanan Prima, (Jakarta: PT. Elex Media Komputindo, 2006), 31.

${ }^{51}$ Mufti Alam Adha, et al, "Pengaruh Program Loyalitas ..., 69-88.

${ }^{52}$ Daryanto dan Ismanto, Konsumen, (Yogyakarta: Gava Media, 2014), 117. el-Qisț: Journal of Islamic Economics and Business (JIEB) 
maupun layanan dari perusahaan. Setelah mereka merasakan bagaimana kualitas produk dan pelayanan, pelanggan akan memberikan informasi yang baik pada pelanggan lain. Sehingga sebagai pengusaha bisa menjual produk berupa barang maupun sebanyak-banyaknya dengan salah satu cara tersebut sebagai faktor pendukung.

Di sisi lain afiliasi atau kemitraan bisnis juga salah satu cara mengembangkan bisnis dengan cara memanfaatkan sosialisasi yang secara terarah dilakukan oleh individu, badan usaha atau organisasi dan kedua belah pihak akan mendapatkan keuntungan seperti yang sudah disepakati bersama. Pembentukan kontak sosial ini menghasilkan sebuah pertalian. Kemitraan bisnis adalah kontrak di antara para mitra perusahaan di mana syarat dan ketentuan kemitraan dinyatakan secara jelas termasuk rasio bagi hasil, kewajiban, aset, investasi dan lainnya.53 Kemitraan sangat penting bagi pebisnis yang baru memulai sebuah usaha, karena mitra akan membantu untuk meningkatkan wawasan mengenai desain, produk, pengemasan dan promosi pemasaran. Menjalin kemitraan bukan suatu yang mudah, karena akan belajar umumnya tidak memahami akses untuk dapat bermitra dengan pengusaha. Untuk itu peran serta perguruan tinggi atau pun pemerintah sangat dibutuhkan untuk memudahkan warga memperoleh akses terhadap perusahaan mitra. Dengan kemitraan, bisnis terbukti lebih tahan lama dan menghasilkan efisiensi serta sumber daya yang dimiliki pihak-pihak yang bermitra karenanya menguntungkan semua pihak. ${ }^{4}$

Sedangkan faktor pendukung terakhir yakni modal sosial yang memiliki arti hubungan-hubungan yang tercipta dan norma-norma yang membentuk kualitas dan kuantitas hubungan sosial dalam masyarakat dalam spectrum yang luas, yaitu sebagai perekat sosial (social glue) yang menjaga kesatuan anggota masyarakat (bangsa) secara bersama-sama. Modal sosial ditransmisikan melalui mekanisme-mekanisme kultural, seperti agama, tradisi, atau kebiasaan sejarah. 55 Konsep modal sosial juga telah mulai diterapkan dalam displin ilmu kewirasuahaan dan beberapa disiplin ilmu lainnya yang berkaitan dengan sosialekonomi. Seperti halnya secara islam, modal sosial diterapkan melalui interaksi kepada masyarakat dengan pengelolaan dana zakat, infaq dan sedekah demi membersihkan harta atau keuangan hasil dari berbisnis. Modal sosial pada dasarnya muncul seiring dengan faktor budaya yang saling mendukung antar sesama dalam sebuah sistem sosial. Membangun kewirausahaan dalam sektor ekonomi kreatif sangat tergantung pada dukungan dari modal sosial. Aspek ini sangat menentukan keberhasilan wirausaha di sektor yang sangat kompetitif dan menuntut kreativitas yang sangat tinggi. Dukungan dari modal sosial akan menjadi katalisator dalam menemukan ide dan kreativitas baru dalam mempertahankan produk yang ditawarkan perusahaan tetap eksis dan mampu bersaing dengan berbagai produk baru yang ditawarkan oleh kompetitor.

53 Ali Hamdan, "SIstem Kemitraan Melalui Kelembagaan Bisnis", Jurnal AdBispreneur, Vol. 1, No. 1, (April, 2016), 73-84.

${ }^{54}$ I Dewa Nyoman Arta Jiwa, "Relationship Marketing ..., 115-251.

55 Rusydan Fathy, "Modal Sosial ..., 1-17. el-Qisț: Journal of Islamic Economics and Business (JIEB) 
Dukungan dari aspek modal sosial akan memudahkan perusahaan dan pebisnis dalam mempromosikan produk mereka kepada komunitas mereka maupun kepada calon pelanggan yang potensial. $5^{6}$

Dari penyusunan strategi pemasaran Islam dalam berwirausaha di sektor ekonomi kreatif pada masa pandemi Covid-19 yang dapat dirancang dan dilaksanakan oleh para pebisnis tidak lupa dalam kondisi saat ini, untuk menjalin hubungan pemasaran dengan pelanggan, pebisnis selaku pelaku usaha juga disarankan untuk dapat menunjukkan kepedulian terhadap konsumen yang sedang mengalami kesulitan pada masa pandemi Covid-19 seperti sekarang. Pelaku usaha dapat menunjukkan kepedulian yang juga bertujuan dalam memasarkan produk, salah satunya dengan menyisihkan sebagian pendapatan dari penjualan produk-produk untuk orang-orang yang membutuhkan.

\section{PENUTUP}

Sektor UMKM mengalami dampak cukup dalam akibat pandemi Covid19. Perilaku ini disebabkan adanya penurunan jumlah pembeli dan berubahnya frekuensi belanja masyarakat. Para pelaku usaha didorong untuk melakukan penyesuaian usaha. Salah satunya yang dapat dilakukan adalah dengan penyusunan strategi pemasaran Islam dalam berwirausaha pada sektor ekonomi kreatif melalui STP (Segmenting, Targetting dan Positioning) untuk menarik konsumen dengan konsep halal market, yaitu halal activist, active customers, dan passive customers. Sedangkan faktor pendukung dalam berwirausaha di sektor ekonomi kreatif pada masa pandemi Covid-19 agar berjalan secara efektif dan efisien di antaranya adalah promotion, service excellet customers rewards, afiliasi atau kemitraan dan modal sosial.

\section{DAFTAR PUSTAKA}

Abdullah, Thamrin. Tantri, Francis. Manajemen Pemasaran. Jakarta: Rajawali Pers, 2016.

Adha, Mufti Alam. Wahyudi, Rofiul. Nahar, Faiza Husnayeni. "Pengaruh Program Loyalitas terhadap Kesetiaan Konsumen pada Industri Halal di Yogyakarta”. Jurnal Ihtifaz: Islamic Economics, Finance and Banking. Vol. 1, No. 1, (Juni, 2018). 69-88.

Asqalani (al), Ahmad b. Ali b. Hajar. Fatḥ al-Bāri Sharh al-Ṣah̄ḥ alBukhārì .Kairo: Dār al-Rayyān li al-Turāth, 1986.

Assauri, Sofian. Manajemen Pemasaran: Dasar, Konsep \& Strategi. cet. Ke-1. ed. 1. Jakarta: RajaGrafindo Persada, 2011.

Assauri, Sofian. Manajemen Pemasaran. Jakarta: Rajawali Pers, 1992.

Azhari, Fadila. Mawardi, Muhammad Kholid. "Peran Modal Sosial Dalam Pengembangan Jaringan Usaha Kecil Menengah”. Jurnal Administrasi Bisnis (JAB). Vol. 59, No. 1, (Juni, 2018). 153-163.

\footnotetext{
56 Fadila Azhari, Muhammad Kholid Mawardi, "Peran Modal Sosial Dalam Pengembangan Jaringan Usaha Kecil Menengah”, Jurnal Administrasi Bisnis (JAB), Vol. 59, No. 1, (Juni, 2018), 153-163.
} 
Barata, A.A. Dasar-dasar Pelayanan Prima. Jakarta: PT. Elex Media Komputindo, 2006.

Betz, N. \& Hackett, G. "The relationship of career-related self-efficacy expectations to perceived career options in college men and women". Journal of Counseling Psychology. Vol. 2 No. 8, (1981). 399-410.

Darmesta, Basu Swastha. Manajemen Pemasaran Modern. Yogyakarta: Liberty, 2002.

Daryanto dan Ismanto. Konsumen. Yogyakarta: Gava Media, 2014.

Fadly, Hawangga Dhiyaul. Sutama. "Membangun Pemasaran Online dan Digital Branding Ditengah Pandemi Covid-19”. Jurnal Ecoment Global. Vol. 5, No. 2, (Agustus, 2020). 213, 223.

Fahlevi, Mirdha dan Yusnaidi. "Entrepreneurial Leadership, Self Effcicacy, Inovasi dan Modal Sosial dalam Berwirausaha di Sektor Ekonomi Kreatif". Jurnal Bisnis dan Kajian Strategi Manajemen. Vol. 4, No. 1, (2020). 13-29.

Fathy, Rusydan. "Modal Sosial: Konsep, Inklusivitas dan Pemberdayaan Masyarakat”. Jurnal Pemikiran Sosiologi. Vol. 6, No. 1, (2019).

Firdausy, Carunia Mulya. Strategi Pengembangan Ekonomi Kreatif di Indonesia. Jakarta: Yayasan Pustaka Obor Indonesia, 2017.

Hamdan, Ali. "Sistem Kemitraan Melalui Kelembagaan Bisnis". Jurnal AdBispreneur. Vol. 1, No. 1, (April, 2016). 73-84.

Hardilawati, Wan Laura. "Strategi Bertahan UMKM di Tengah Pandemi Covid19”. Jurnal Akuntansi dan Ekonomika. Vol. 10, No. 1, (Juni, 2020). 89-99.

"Model Pemasaran Hubungan Pelanggan, Inovasi Dan ECommerce Dalam Meningkatkan Kinerja Pemasaran Ukm Di Pekanbaru”. Jurnal Akuntansi Dan Ekonomika. Vol. 9, No. 2, (2019). 213222.

Heriyadi. "Strategi Positioning dalam Persaingan Bisnis". Asian Journal of Innovation and Entrepreneurship. Vol. 3, No. 3, (September 2018). 261-272.

Intitut Tazkia. Tujuh Paket Ekonomi dan Keuangan Syariah Mengatasi Dampak Krisis Covid-19. Bogor: Intitut Tazkia, 2020.

Iskandar, Azwar. Possumah, Bayu Taufiq. Akbar, Khaerul. "Peran Ekonomi dan Keuangan Sosial Islam Saat Pandemi Covid-19”. SALAM: Jurnal Sosial dan budaya Syar-I. Vol. 7, No. 7, (2020). 625-638.

Jiwa, I Dewa Nyoman Arta. "Relationship Marketing, Power dan Loyalitas pada Hubungan Bisnis”. Jurnal Mitra Manajemen. Vol. 2, No. 3, (2018). 115251.

Jurnal Entrepreneur, "Strategi Pemasaran Produk Bisnis di Tengah Pandemi Corona", https://www.jurnal.id/id/blog/7-strategi-pemasaranproduk-ukm-saat-krisis- virus-Covid-19/, diakses pada tanggal 24 Mei 2020.

Kasmir. Etika Customer Service. Jakarta: PT RajaGrafindo Persada, 2005. 
Kementerian Keuangan, "Solusi Ekonomi dan Keuangan Islam Saat Pandemi COVID-19”, https://www.kemenkeu.go.id/publikasi/artikel-danopini/solusi-ekonomi-dan- keuangan-islam-saat-pandemi-Covid-19/, diakses pada tanggal 20 Mei 2020.

Kementerian Koperasi dan Usaha Kecil dan Menengah, Siaran Pers, http://www.depkop.go.id/siaran-pers, diakses pada tanggal 18 Juni 2020.

Kotler, Philip. Marketing. Jilid 1. Jakarta: Erlangga, 1987. . Manajemen Pemasaran. Edisi Mileinium. Jakarta: PT. Indeks Kelompok Gramedia, 2000.

Moleong, Lexi J. Metodologi Penelitian Kualitatif. Bandung: PT Remaja Rosdakarya, 2013.

Pearce, John A., Robinson, Richard B. Manajemen Strategi. Jakarta: Salemba Empat, 2014.

Peraturan Presiden Nomor 72 Tahun 2015 tentang Perubahan Atas Peraturan Presiden Nomor 6 Tahun 2015 tentang Badan Ekonomi Kreatif.

Rivai, Veithzal. dkk, Islamic Business and Economic Ethics. Jakarta: Bumi Aksara, 2012.

Sugiyono. Metode Penelitian Kuantitatif, Kualitatif dan $R \& D$. Bandung: Alfabeta, 2019.

Sumarni, Yenti. "Manajemen Ekonomi Islam dalam Menangani Pandemi Coronavirus Disease (Covid-19) di Indonesia”. Jurnal Baabu Al-Ilmi. Vol. 5, No. 1. (April, 2020). 117-127.

Tamtama, Noviadry Nur. Peran Relationship Marketing dalam Menciptakan Loyalitas Pelanggan. Tesis - Universitas Muhammadiyah Surakarta, 2017.

Tasruddin, Ramsiah. "Strategi Promosi Yang Efektif”. Jurnal Al-Khitabah. Vol. II, No. 1, (Desember, 2015). 107-116.

The World Bank, "World Bank Group and Covid-19 (Coronavirus)", https://www.worldbank.org/en/who-we-are/news/coronavirus-covid19, diakses pada tanggal 20 Mei 2020.

Tjiptono, Fandi. Pemasaran Jasa. Yogyakarta: Andi Offset, 2014.

Tjiptono, Fandy. Strategi Pemasaran. Yogyakarta: ANDI Offset, 2018.

Wijaya, Hari dan Sirine, Hani. "Strategi Segmenting, Targeting, Positioning serta Strategi Harga”. Asian Journal of Innovation and Entrepreneurship. Vol. 1, No. 3, (September 2016). 175-191. 